\title{
Cytotoxic effects of cyanoacrylates used as retrograde filling materials. An in vitro analysis
}

\section{Efeitos citotóxicos de cianoacrilatos usados como material de obturação retrógrada. Uma análise in vitro}

\author{
Cledson Lima de Azevedo* \\ Márcia Martins Marques** \\ Antonio Carlos Bombana**
}

\begin{abstract}
Cyanoacrylate has been used in medicine and dentistry for many years. It has been used as a postextraction dressing and retrograde filling material in endodontic surgery. The aim of this study was to evaluate the cytotoxic effects of Histoacryl and other two homologue ethyl cyanoacrylates, Super Bonder and Ultrabond, on cultured fibroblasts, using the Trypan blue dye exclusion assay. The cyanoacrylates were applied to round glass coverslips, which were placed in contact with NIH 3T3 cells. After 0, 6, 12 and $24 \mathrm{~h}$ (short-term assay; viability) and 1, 3, 5 and 7 days (long-term assay; survival), the cells were examined under phase light microscopy and counted. The data were compared by the Kruskal-Wallis test. In the short-term experiments, only the cultures of the Ultrabond group (GIV) presented significant smaller percentages of cell viability than the cultures of the other groups (GI: control; GII: Super Bonder; GIII: Histoacryl). Although the cultures of the Super Bonder group (GII) presented smaller percentages of cell viability than cultures of the other groups (GI, GIII, GIV) at the long-term assay, this group was the only experimental group presenting a continuous and progressive cell growth. Our results have shown an in vitro biocompatibility of Histoacryl and ethyl cyanoacrylate homologues. These cyanoacrylates could therefore be of importance for endodontic purposes.
\end{abstract}

DESCRIPTORS: Biocompatible materials; Cell culture; Cyanoacrylates.

RESUMO: Os cianoacrilatos tem encontrado aplicabilidade tanto na Medicina como na Odontologia há muitos anos. Têm sido usados como curativo após exodontias, bem como para obturação retrógrada em cirurgia parendodôntica. $\mathrm{O}$ objetivo deste estudo foi o de avaliar o efeito citotóxico do Histoacryl e outros dois homólogos etil cianoacrilatos: SuperBonder e Ultrabond, em cultura de fibroblastos, empregando ensaios de viabilidade pela exclusão de células coradas pelo azul de Trypan. Os cianoacrilatos foram aplicados em laminulas de vidro circulares, que foram colocadas sobre cultura de fibroblastos NIH - 3T3. Após 0, 6, 12 e 24 horas (resposta celular imediata - curto prazo) e 1, 3, 5 e 7 dias (sobrevivência celular - longo prazo), foram efetuadas contagens celulares em microscópio de fase. Os dados obtidos foram analisados valendo-se do teste estatístico de Kruskal-Wallis. No experimento de curto prazo, somente as culturas do grupo Ultrabond (GIV) apresentaram porcentagens de viabilidade celular significantemente menores que a dos outros grupos (GI: controle; GII: Super Bonder; GIII: Histoacryl). Embora as culturas do grupo Super Bonder (GII) apresentassem porcentagens de viabilidade celular menores que as dos outros grupos (GI, GIII, GIV) no experimento de longo prazo, esse grupo foi o único que mostrou crescimento celular progressivo e contínuo. Nossos resultados mostraram biocompatibilidade in vitro tanto do Histoacryl como dos outros dois homólogos etil cianoacrilatos. Esses cianoacrilatos podem ser importantes para finalidades biológicas.

DESCRITORES: Materiais biocompativeis; Cultura de células; Cianoacrilatos.

\section{INTRODUCTION}

Endodontic treatment is based on disinfection and enlargement of root canals. As a result of this treatment, the dentine permeability increases. The opening of dentine tubules is important for improving the final sealing of the root canal (Taylor et al. $\left.{ }^{17}, 1997\right)$. However, when highly permeabilized, the dentine becomes more vulnerable to reinfection (Michelich et al. ${ }^{15}, 1980$ ). Furthermore, when conventional treatment is unsuccessful, periapical surgery may be necessary. Then, the retrograde root canal filling is done to hermetically seal the root canal system against leakage of irritants from the root canal system into periapical tissue (Barkhordar et al. ${ }^{2}$, 1988).

For many years, amalgam has been accepted as the material of choice for retrofillings in endodontic surgery. However, poor results in leakage as well as concern about corrosion products, and electrochemical reactions have led researchers to

*MSD; **PhD - Department of Endodontics, School of Dentistry, University of São Paulo. 
Azevedo CL de, Marques MM, Bombana AC. Cytotoxic effects of cyanoacrylates used as retrograde filling materials. An in vitro analysis. Pesqui Odontol Bras 2003;17(2):113-8.

look for alternative materials (Dorn, Gartner', 1990). The suggested materials include cyanoacrylates, Cavit, gold foil, composites, glass ionomers, IRM, Super EBA (Dorn, Gartner ${ }^{9}$, 1990) and bone cement (Holt, Dumsha ${ }^{13}, 2000$ ).

Cyanoacrylate has been used in medicine and dentistry for many years (Barkhordar et al. ${ }^{2}, 1988$ ). It has been used as a postextraction dressing, a tissue adhesive, and for pulp capping (Bhaskar et al. ${ }^{5,6,7}, 1972$, 1969, 1966; Bhaskar, Frisch ${ }^{8}$, 1968). Moreover, because of its bonding property, cyanoacrylate was evaluated as both root canal sealer (Isaac, Bombana ${ }^{14}$, 1999) and a retrograde filling material (Barkhordar et al. ${ }^{2}$, 1988; Bhaskar et al. ${ }^{5}$, 1972; Torabinejad et al. ${ }^{18}, 1984$; Azevedo et $a l .{ }^{1}$, 1996). These studies indicated that cyanoacrylates have potential use in endodontics.

Biocompatibility of root-end filling materials has been the subject of numerous studies in the past (Zhu et al. $\left.{ }^{20}, 1999\right)$. However, there are only a few studies on the cytotoxic effect of cyanoacrylates using the cell culture technique (Galil et al. $\left.{ }^{11}, 1984\right)$. With this in mind, and based on the prospect that cyanoacrylate could be used as both a dentine impermeabilizing substance and a retrograde filling material, improving the final root canal sealing, we analyzed the cytotoxic effects of three different commercially available cyanoacrylates in cultured fibroblasts.

\section{MATERIAL AND METHODS}

The toxicity of three different commercial presentations of cyanoacrylate was measured in vitro. NIH 3T3 cells (CRL 1658) obtained from American Type Culture Collection (Rockville, MD, USA) were grown at $37^{\circ} \mathrm{C}$ in Dulbecco's Modified Eagle medium (DMEM, Sigma Chemical Co., St. Louis, MO, USA) supplemented by 10\% fetal bovine serum (Cultilab, Campinas, SP, Brazil) and 1\% antibiotic-antimycotic solution (Sigma Chemical Co., St. Louis, MO, USA) in a humid $5 \% \mathrm{CO}_{2}$ atmosphere. Experimental groups were as follow: GI: control, cultures that received plain round coverslips, GII: cultures that received round coverslips coated by Super Bonder (Loctite Brasil, São Paulo, SP, Brazil), GIII: cultures that received round coverslips coated by Histoacryl (B. Braun Melsungen AG, Melsungen, Germany), GIV: cultures that received round coverslips coated by Ultrabond (Garin Cia. Ltda., São Paulo, SP, Brazil). Both an immediate or short-term response and a long-term survival that measure the retention of the self-renewal capacity of the cells were analyzed.

\section{Short-term assay (cell viability)}

Cells $\left(2 \times 10^{4}\right)$ were plated on $60 \mathrm{~mm}$ Petri dishes. Three days later, the experimental cultures received coverslips coated by the different cyanoacrylates, and the control cultures received plain coverslips. After 0, 6, 12 and $24 \mathrm{~h}$ the cells were counted and viability curves were made.

\section{Long-term assay (cell survival)}

Cells $\left(1 \times 10^{4}\right)$ were plated on $60 \mathrm{~mm}$ diameter culture dishes. Treated cultures received coverslips coated by cyanoacrylates. Control cultures received plain coverslips. One, 3, 5 and 7 days after seeding the cells were counted and growth curves were plotted.

\section{Growth and viability cell curves}

Growth curves were carried out as described elsewhere $\left(\right.$ Freshney $^{10}$, 2000; Zaccaro Scelza et al. $\left.{ }^{19}, 2001\right)$. Briefly, cell counts were determined by counting the viable cells in a hemocytometer using the Trypan blue dye exclusion assay. For each time period, three dishes of each group were counted. The number of viable cells harvested from each Petri dish was obtained by the following mathematical equation: UC $\times$ D $\times 10^{4} / \#$ SQ, where $\mathrm{UC}=$ unstained cell count (viable cells), $\mathrm{D}=$ the dilution of the cell suspension, and $\# \mathrm{SQ}=$ number of squares of the hemocytometer counted.

The viability percentage of the cell population of each Petri dish was obtained by the following mathematical equation: UC/TC $\mathrm{x} 100$, where $\mathrm{UC}=$ unstained cell count (viable cells) and TC = total cell count (stained plus unstained cells).

\section{Statistical analysis}

Each data point corresponded to the mean \pm SEM (standard error of the mean) of either cell count or percentage of cell viability from 3 dishes. The data were compared by the Kruskal-Wallis test. The level of significance was $5 \%(\mathrm{p}<0.05)$.

\section{Morphological analysis}

The morphology and the distribution of cells were monitored throughout the experimental time. Using phase light microscopy, the relationships between the cells grown in the Petri dishes and the coverslips of all groups were studied. Additionally, the individual morphology of the cells, as well as the presence of both living cells and dead cells was 
Azevedo CL de, Marques MM, Bombana AC. Cytotoxic effects of cyanoacrylates used as retrograde filling materials. An in vitro analysis. Pesqui Odontol Bras 2003;17(2):113-8.

analyzed. Phase photomicrographs were obtained from a Zeiss Axiophot microscope (Carl Zeiss Inc., Oberköchen, Germany).

\section{RESULTS \\ Short-term assay}

Throughout the experimental time $(0-24 \mathrm{~h})$, controls and treated cultures maintained stable cell viability $(87.67 \%$ to $96.53 \%)$, except for the cultures treated with Ultrabond (GIV) (Graph 1). These cultures presented a viability that ranged from $82.73 \%$ to $90.13 \%$, which was significantly smaller than the viability rates of the other groups, especially at $12 \mathrm{~h}$. The other two groups (GII: Super Bonder, GIII: Histoacryl) mostly behaved as the control cultures (GI).

\section{Long-term assay}

There was a progressive cell growth in the control cultures (GI) from day 1 to 7 (Graph 2A). Cultures treated with Super Bonder (GII) also had progressive increase in cell numbers. However, this group presented significantly fewer cells than control cultures (GI) throughout the experimental time. Cultures treated with Histoacryl (GIII) and Ultrabond (GIV) presented significantly higher numbers of cells when compared to the control cultures until 3 days after seeding. From this point

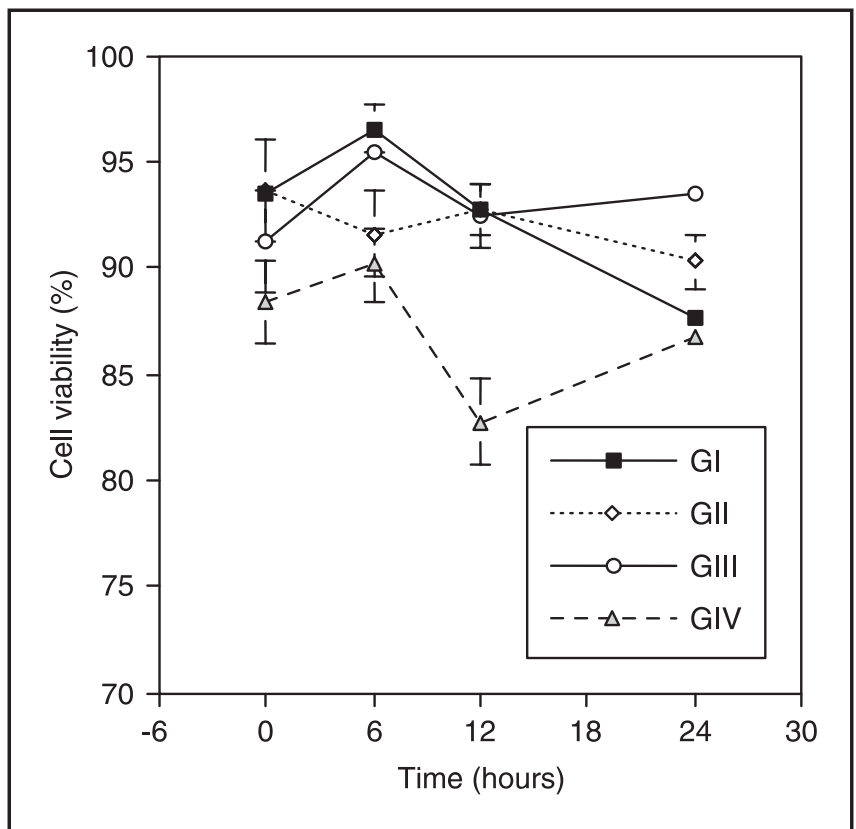

GRAPH 1 - Viability curves of NIH 3T3 cells in the short-term assay. Note that cultures of Ultrabond group (GIV) present significantly smaller percentages of cell viability than the cultures of the other groups. $(\mathrm{p}<0.05)$. on, cultures from group III still increased cell numbers until day 5 , when a decrease was observed, reaching values significantly smaller than those of control cultures at the end of the experimental time. Cultures from group IV (Ultrabond) presented a progressive decrease in cell numbers after day 3 , with values $(p<7.302)$ significantly smaller than those of control cultures (GI).

The percentage of cell viability of control cultures (GI) was stable around 95\% during all of the experimental time (Graph 2B). Until day 5, cultures of group II (Super Bonder) presented significantly smaller percentages of cell viability $(p<11.860)$ than those of the other groups. Then, there was a recovery of the percentage of cell viability in this group (GII), reaching the viability values of the control cultures at the end of the experimental time. The percentage of cell viability of cultures treated with Histoacryl (GIII) and Ultrabond (GIV) after 5 days in culture dropped at day 7, reaching values of $64.1 \%$ and $56.87 \%$, respectively.

\section{Phase microscopy}

Representative phase micrographs of NIH-3T3 cells, control and treated with cyanoacrylates, are shown in Figure 1. Control cultures (GI; Figures 1A, B) and cultures treated with Super Bonder (GII; Figures 1C, D) showed the morphological findings of this study. Control cells at day 1 (Figure 1A) were spindle-shaped or stellate, and grew in intimate contact with the plain glass coverslips. Several cells in division were observed at this time. Three days later (Figure 1B) most of the plastic culture surface was covered by fibroblasts. Cultures treated with Super Bonder (GII) also were spindle-shaped or stellate. At day 1 (Figure 1C) there were smaller cell counts in treated cultures (GII) than in controls (GI), but the cells were also in close contact with the coverslips coated by cyanoacrylate. Three days later in GII the cells presented a change in shape, becoming more polygonal and epithelial-like. There was an intimate contact of cells with the cyanoacrylate coated glass coverslips. Clusters of dead cells were present. Throughout the cell monolayers, unattached round cells were observed, resembling cells in division.

\section{DISCUSSION}

Measurements of cytotoxicity and viability in vitro are specifically designed to assay viability or survival as the major parameter of response to a substance under study, thereby establishing a 
Azevedo CL de, Marques MM, Bombana AC. Cytotoxic effects of cyanoacrylates used as retrograde filling materials. An in vitro analysis. Pesqui Odontol Bras 2003;17(2):113-8.
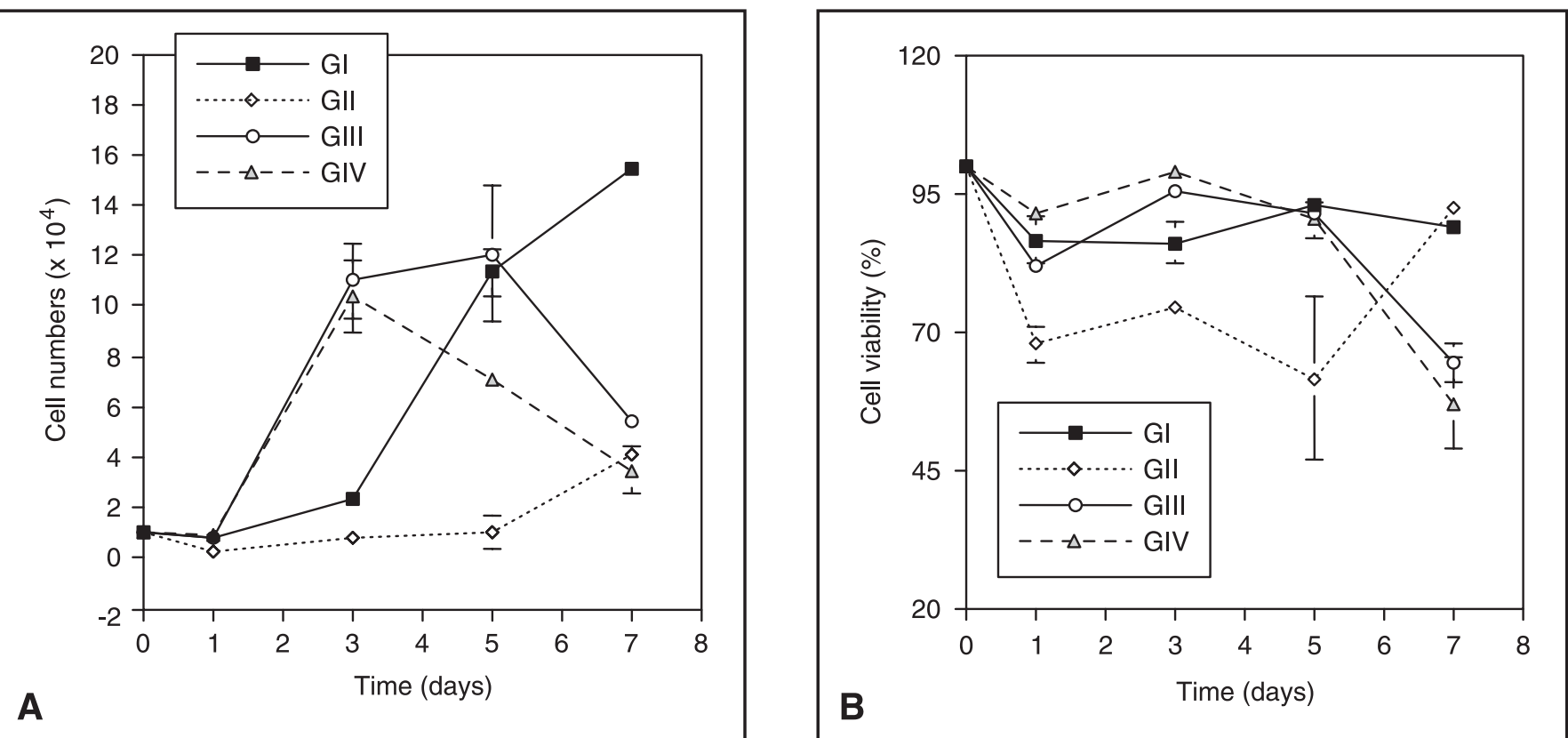

GRAPH 2 - Graphs of cell growth and cell viability in the long-term assay. A: growth curves of control (GI) and experimental (GII-GIV) cultures. Note that only control cultures (GI) and cultures treated with Super Bonder (GII), although exhibiting a delay in growing, present progressive growth during all experimental times. B: viability curves of NIH 3T3 cells. Control cultures (GI) present a stable viability around 95\%. Cultures from group II (Super Bonder) present smaller percentages of cell viability than the cultures of the other groups only until day 5 . The other two groups (GIII and GIV) present a continuous drop in the percentage of cell viability after day 5 in culture.

cheaper, more reproducible substitute for a test otherwise performed in animals. These assays can be divided into two classes: an immediate or short-term response and a long-term survival usually measured by the retention of the self-renewal capacity of cells $\left(\right.$ Freshney $\left.{ }^{10}, 2000\right)$. Using these assays, we have demonstrated that all cyanoacrylates tested are biocompatible. Ultrabond presented significantly smaller percentages of cell viability than the viability of the cultures of other groups. Although Super Bonder had shown smaller percentages of cell viability than those of the other groups at the long-term assay, this group (GII) was the only experimental group presenting a continuous and progressive cell growth. The cultures treated with Histoacryl (GII) and Ultrabond (GIV) exhibited a diminishing of cell numbers after day 3 in culture.

For testing biomaterials in cell culture, especially solids, it is recommended to apply these materials to the cells as they will be used in future clinical procedures (Spångberg, Pascon ${ }^{16}, 1988$ ). For this reason, we covered glass coverslips with the different cyanoacrylates and then immersed these coated coverslips upside down into the culture dishes, to obtain a direct contact of the testing substances with the cultured fibroblasts. To rule out the effect of cell physical damage caused by the coverslips themselves, we used plain coverslips in the control cultures.

Initial uses of cyanoacrylates for endodontic purposes focused on the pulpal response to these materials. Clinical and histological analyses of exposed pulpal tissue treated with cyanoacrylate spray showed immediate hemostasis, low inflammation and the formation of a dentinal bridge deposited directly on the cyanoacrylate dressing (Bhaskar, Frisch ${ }^{8}$, 1968; Berkman et al. ${ }^{4}$, 1971). Later on, cyanoacrylate was evaluated as both root canal sealer (Torabinejad et al. ${ }^{18}, 1984$ ) and a retrograde filling material (Barkhordar et al. ${ }^{2}, 1988$; Isaac, Bombana ${ }^{14}$, 1999; Azevedo et al. ${ }^{1}$, 1996). These studies indicated that cyanoacrylates have a potential use in endodontics.

The ideal material for the perfect retrofilling should have many properties that allow a hermetic seal and guarantee biocompatibility. Hence, such a material should exhibit minimal leakage, low cytotoxicity, be easily manipulated, allow connective tissue attachment, be bacteriostatic, and tolerate a moist environment (Holt, Dumsha ${ }^{13}$, 2000).

Azevedo et al. ${ }^{1}$ (1996) analyzed by comparison the sealing quality of n-butyl-2-cyanoacrylate (Histoacryl) and of amalgam as retrofilling materi- 
Azevedo CL de, Marques MM, Bombana AC. Cytotoxic effects of cyanoacrylates used as retrograde filling materials. An in vitro analysis. Pesqui Odontol Bras 2003;17(2):113-8.
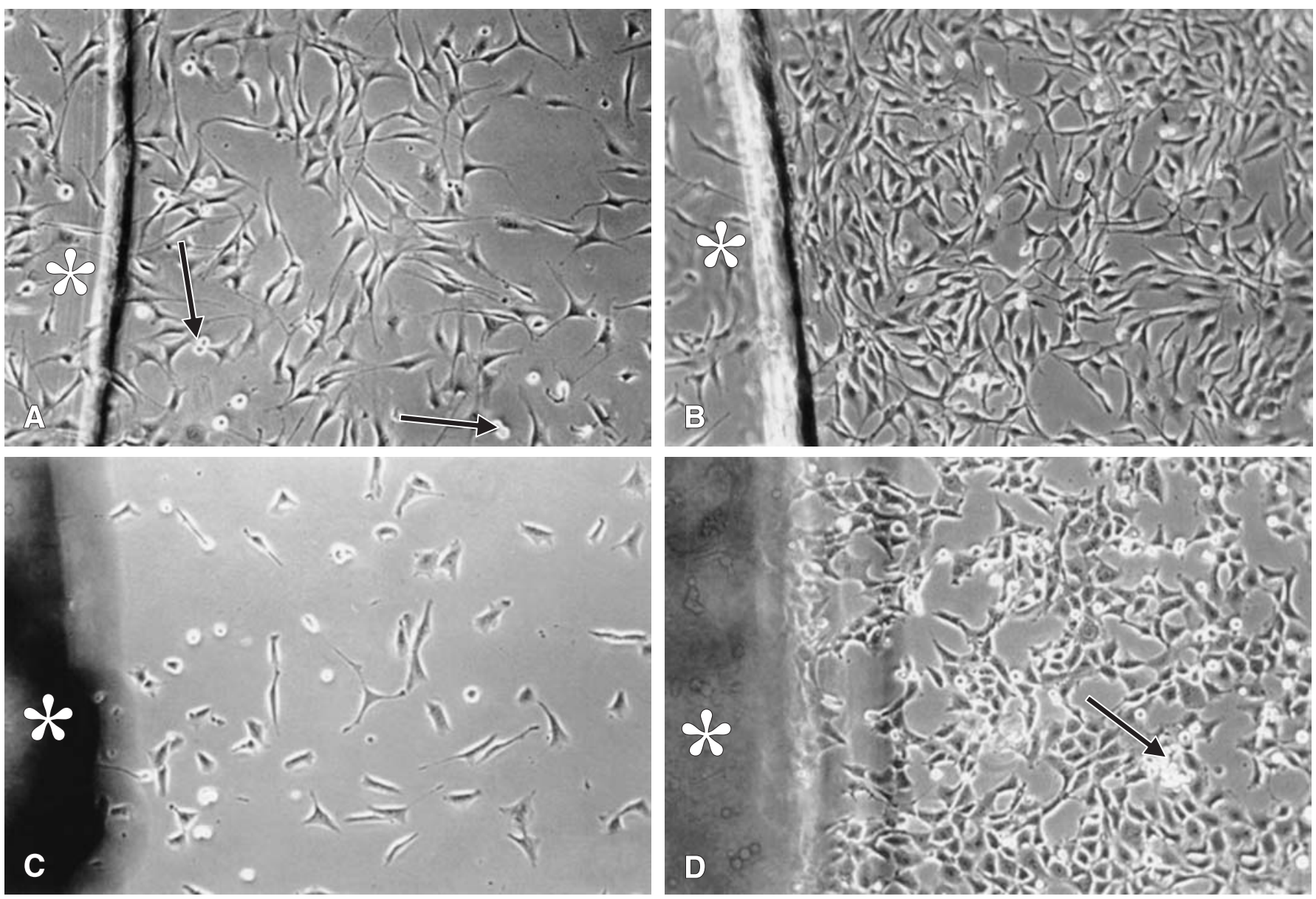

FIGURE 1 - Representative phase micrographs of NIH 3T3 cells of the control group (GI, A, B) and of those treated with cyanoacrylate (GII, C, D) show the morphological findings of this study. A: Control cells at day 1 grow in intimate contact with the plain glass coverslips (*). Several cells in division are observed at this time (arrows). B: Three days later most of the plastic culture surface is covered by fibroblasts. C: Cultures treated with Super Bonder (GII) at day 1 present smaller cell numbers than control cultures (GI), but the cells are also in close contact with the coverslips coated by cyanoacrylate $\left({ }^{*}\right)$. D: Three days later treated cells present a polygonal and epithelial-like shape. There is an intimate contact of cells with the Super Bonder coated glass coverslips (*). Clusters of dead cells are present (arrow; *). Throughout the cell monolayers, unattached round cells are observed resembling cells in division.

als. Dye penetration, as well as scanning microscopy examination showed that Histoacryl presented better sealing quality than did amalgam. Issac, Bombana ${ }^{14}$ (1999) compared the root canal apical sealing obtained by several different filling materials, including an n-butyl-2-cyanoacrylate (Histoacryl). The authors concluded that Histoacryl used either as filling material or as filling material coating presented better sealing quality than did the other materials.

Several studies have been conducted to evaluate the bonding capacity of cyanoacrylates to dentin and enamel (Herod $\left.{ }^{12}, 1990\right)$. Beech $^{3}, 1972$, found that the methyl, ethyl and isobutyl2-cyanoacrylate formed strong bonds with dentin, acid treated enamel and two polymeric restorative materials under aqueous conditions. The adhesion to dentin was probably a result of covalent bonds being formed with the organic constituents of dentin.

Studies exploring the biologic receptivity of some cyanoacrylate homologues, such as ethyl, propyl and butyl monomers were conducted by Bhaskar et al. ${ }^{7}$ (1966). All the homologues produced immediate hemostasis in tongue injuries in rats and a typical cicatrization occurred. In 1966, an examination of the hexyl, heptyl and octyl cyanoacrylates showed that the higher homologue compounds were better tolerated by tissues than the lower homologues (Bhaskar et al. $\left.{ }^{7}, 1966\right)$. Following these initial studies, research on biocompatibility focused primarily on the butyl 
Azevedo CL de, Marques MM, Bombana AC. Cytotoxic effects of cyanoacrylates used as retrograde filling materials. An in vitro analysis. Pesqui Odontol Bras 2003;17(2):113-8.

cyanoacrylate homologue with promising results (Herod $\left.{ }^{12}, 1990\right)$.

The only cell culture cytotoxicity analysis of cyanoacrylates until now was performed by Galil et $a l^{11}$, 1984. By applying polymerized cyanoacrylates into Petri dishes containing monolayers of L-929 mouse fibroblasts, these authors showed some evidence of cytotoxicity. Their results suggested that soluble degradation products of cyanoacrylates are responsible for the cytotoxic effect observed. All cyanoacrylates tested in our study left more than $82 \%$ of the cells alive within the first 24 h. However, Galil et al. ${ }^{11}$ (1984) showed total cell death within the first $12 \mathrm{~h}$. This discrepancy of results could be due to the cyanoacrylate formulation that might have been more toxic in the eighties than it is nowadays. On the other hand, our study showed a greater deal of cell death after 5 days in culture in the Ultrabond group (GIV) in the long-term assay. This result is in accordance

\section{REFERENCES}

1. Azevedo CL, Lage Marques JL, Rode SM. Sealing quality of Histoacryl when compared to amalgam as retrofilling. J Endod 1996;22:211.

2. Barkhordar RA, Javid B, Abassi J, Watanabe LG. Cyanoacrylate as a retrofilling material. Oral Surg Oral Med Oral Pathol 1988;65:468-73.

3. Beech DR. Bonding of alkyl 2-cyanoacrylates to human dental and enamel. J Dent Res 1972;51:1438-42.

4. Berkman MD, Cucolo FA, Levin MP, Brunelle LJ. Pulpal response to isobutyl cyanoacrylate in human teeth. J Am Dent Assoc 1971;83:140-5.

5. Bhaskar SN, Beasley JD, Ward JP, Cutright DE. Human pulp capping with isobutyl cyanoacrylate. J Dent Res 1972;51:58-61.

6. Bhaskar SN, Cutright DE, Boyers RC. Pulp capping with isobutyl cyanaoacrylate. J Am Dent Assoc 1969;79:640-4.

7. Bhaskar SN, Jacoway JR, Margetis PM, Leonard F. Oral tissue response to chemical adhesives (cyanoacrylates). Oral Surg Oral Med Oral Pathol 1966;22:4394-404.

8. Bhaskar SN, Frisch J. Use of cyanoacrylate adhesives in dentistry. J Am Dent Assoc 1968;77:831-7.

9. Dorn SO, Gartner AH. Retrograde filling materials: a retrospective success-failure study of amalgam, EBA, and IRM. J Endod 1990;16:391-3.

10. Freshney, RI. Culture of animal cells. A manual of basic technique. $4^{\text {th }}$ ed. New York: Wiley-Liss; 2000.

11. Galil KA, Schofield ID, Wright GZ, Ryall L. Cytotoxic efffect of two cyanoacrylates: an in vitro study. J Dent Res 1984;63:325a. with the observations of Galil et al. ${ }^{11}$ (1984) where one type of cyanoacrylate reached its maximum cytotoxicity after 4 days.

The close contact between the fibroblasts and the cyanoacrylate coated coverslips demonstrated some degree of biocompatibility of these substances. Additionally, the presence of dividing cells three days after seeding in the group treated with Super Bonder also indicates the preservation of the self-renewal capacity of these cells. These results together with the clinical findings reported in the literature are encouraging for the use of cyanoacrylates in endodontics.

\section{CONCLUSIONS}

Our results have shown an in vitro biocompatibility of both butyl and ethyl cyanoacrylate homologues. Thus, these materials could be of importance for endodontic purposes.

12. Herod EL. Cyanoacrylates in dentistry: a review of the literature. J Can Dent Assoc 1990;56:331-4.

13. Holt GM; Dumsha TC. Leakage of amalgam, composite, and Super-EBA, compared with a new retrofill material: bone cement. J Endod 2000;26:29-31.

14. Isaac APMAS, Bombana AC. In vitro sealing ability of Histoacryl as a retrofilling material. $J$ Dent Res 1999;78:976.

15. Michelich VJ, Schuster GS, Pashley DH. Bacterial penetration of human dentin in vitro. J Dent Res 1980; 59:1398-403.

16. Spångberg L, Pascon EA. The importance of material preparation for the expression of cytotoxicity during in vitro evaluation of biomaterials. J Endod 1988;14: 247-50.

17. Taylor JK, Jeansonne BG, Lemon RR. Coronal leakage: effects of smear layer, obturation technique, and sealer. J Endod 1997;23:508-12.

18. Torabinejad M, Kahn H, Bankes D. Isopropyl cyanoacrylate as a root canal sealer. J Endod 1984;10:304-7.

19. Zaccaro SMF, Daniel RL Santos EM, Jaeger MM. Cytotoxic effects of $10 \%$ citric acid and EDTA-T used as root canal irrigants: an in vitro analysis. J Endod 2001;27(12):741-3.

20. Zhu Q, Safavi KE, Spångberg LSW. Cytotoxic evaluation of root-end filling materials in cultures of human osteoblast-like cells and periodontal ligament cells. J Endod 1999;25:410-2. 